\title{
Kajian dan Evaluasi Sistem Suplai Energi Listrik PLTS dan PLTB di Kampus Teknik Elektro Universitas Udayana Bukit Jimbaran Bali
}

\author{
Intan Aprilia Medina ${ }^{1}$, I. A. D. Giriantari ${ }^{2}$, I. W. Sukerayasa ${ }^{3}$
}

\begin{abstract}
Hybrid PLTS and PLTB can overcome the demand for electrical energy, so it need a hybrid power plant (PLTH). One application of the concept of hybrid power generation with microgrid system is located at Electrical Engineering Program Faculty of Engineering Udayana University Bukit Jimbaran, Bali. This PLTH is a collaborative project between Udayana University and ESDM Ministry. PLTH in Electrical Engineering Udayana requires the study and evaluate the energy supply system from the power generation to know the performance of PLTS and PLTB. This study uses software HOMER (Hybrid Optimization Model For Electric Renewable) free trial version. A performance analysis show that PLTS and PLTB cannot full covering the electricity load in September, October and November 2017. The real condition of electricity production from PLTS reaches $26.750,83 \mathrm{kWh}$ per year, while the HOMER simulation is $35.956 \mathrm{kWh}$ per year. Real condition of electric energy production from PLTB reach 4555,78 $k W h$ per year, while the HOMER simulation is $33521 \mathrm{kWh}$ per year. The whole production of HOMER simulated electrical energy is bigger than real condition. The reduction of energy reaches $31306,62 \mathrm{kWh}$ per year or $64 \%$ of the total electric loads.

Intisari- Adanya pembangkit listrik hibrid (PLTH) dapat mengatasi permintaan energi listrik yang ada saat ini. Salah satu penerapan konsep pembangkit listrik hibrid dengan sistem jaringan mikro berada di Program Studi Teknik Elektro Fakultas Teknik Universitas Udayana Bukit Jimbaran, Bali. PLTH ini merupakan proyek kolaborasi antara Universitas Udayana dan Kementerian ESDM. PLTH di Teknik Elektro Udayana membutuhkan kajian dan evaluasi dari sistem suplai energi dari pembangkitan tenaga listrik tersebut agar mengetahui performa PLTS dan PLTB. Studi ini menggunakan software HOMER (Hybrid Optimization Model For Electric Renewable) free trial version. Telah dilakukan analisis performa yang menunjukkan bahwa PLTS dan PLTB gedung DH tidak mampu memenuhi beban listrik pada bulan September, Oktober serta November 2017. Produksi energi listrik PLTS di Teknik Elektro mencapai $26.750,83 \mathrm{kWh}$ per tahunnya, sedangkan pada simulasi HOMER sebesar $35.956 \mathrm{kWh}$ per tahun. Produksi energi listrik PLTB di Teknik Elektro mencapai 4555,78 kWh per tahunnya, sedangkan pada simulasi HOMER lebih besar sebesar $33521 \mathrm{kWh}$ per tahun. Seluruh produksi energi listrik simulasi HOMER lebih besar dari kondisi riil di lapangan. Pengurangan energi listrik setelah adanya hibrid ini mencapai $31306,62 \mathrm{kWh}$ per tahun atau sebesar $64 \%$ dari total beban listrik.
\end{abstract}

Kata Kunci-Hibrid, PLTS, PLTB, Penghematan Energi Listrik

\footnotetext{
${ }^{1}$ Mahasiswa, Program Studi Teknik Elektro Fakultas Teknik Universitas Udayana, Pulau Adi No. 52 Denpasar, INDONESIA Hp: 089678759074; e-mail:intanapm@gmail.com

${ }^{2,3}$ Staf Pengajar Program Studi Teknik Elektro Fakultas Teknik Universitas Udayana, Jalan Kampus Bukit Jimbaran 80361 INDONESIA telp: 0361-703315; fax: 0361-703315
}

\section{Pendahuluan}

Energi baru terbarukan merupakan salah satu solusi untuk mengatasi kebutuhan listrik yang semakin meningkat dengan proyeksi rata-rata kebutuhan listrik di Indonesia sebesar 6,86\% berdasarkan data RUPTL PT PLN (Persero) 2018-2027. Hal ini mendorong adanya upaya pencapaian target porsi energi baru dan terbarukan (EBT) sekitar 23\% pada tahun 2025 [1]. Penggunaan energi terbarukan di Indonesia sebagai salah satu alternatif untuk meminimalkan kerusakan lingkungan sebagai dampak kegiatan eksplorasi. PLTS (Pembangkit Listrik Tenaga Surya) dan PLTB (Pembangkit Listrik Tenaga Bayu) merupakan contoh pengembangan dari pemanfaatan energi terbarukan yang memanfaatkan energi surya dan energi angin sebagai energi primer. Pembangkit Listrik Tenaga Hibrid ini dapat digunakan pada sistem jaringan listrik mikro (microgrid) [2].

Implementasi konsep microgrid dan PLTH (Pembangkit Listrik Hibrid) sedang berkembang di Indonesia. Penerapan konsep PLTH dengan sistem jaringan mikro pada area pendidikan ini terletak di Universitas Udayana, tepatnya di Program Studi Teknik Elektro Fakultas Teknik Bukit Jimbaran,Bali. PLTH di Program Studi Teknik Elektro Universitas Udayana merupakan hibridisasi antara PLTS dan PLTB yang menghasilkan energi listrik dalam skala kecil. PLTH ini terletak di atas atap gedung DH seluas 33 meter $\mathrm{x}$ 16.5 meter. Gedung $\mathrm{DH}$ adalah tempat dimana aktifitas pembelajaran mahasiswa dilaksanakan. Letak Geografis gedung DH yaitu 08'47'45,3'’LS 115¹0'26'” BT [3][10].

Pembangkit Listrik Hibrid yang ada di Program Studi Teknik Elektro Universitas Udayana membutuhkan evaluasi dari sistem suplai energi dari pembangkitan tenaga listrik tersebut agar mengetahui kinerja PLTH (PLTS dan PLTB). Kajian dan evaluasi kinerja PLTH yang dimaksudkan yaitu apakah sistem pembangkit tersebut mampu mensuplai energi listrik dan memenuhi kebutuhan listrik secara baik dan kontinyu di Program Studi Teknik Elektro Universitas Udayana, khususnya kebutuhan listrik yang terdapat di gedung DH. Evaluasi sistem PLTH ini menggunakan simulasi HOMER (Hybrid Optimization Model For Electric Renewable) free trial version. Simulasi ini dapat membantu menganalisis kelayakan dari sebuah sistem PLTH yang dilihat dari data beban listrik dan data keluaran sistem suplai pembangkit listrik. Penelitian ini menggunakan data konsumsi energi listrik gedung DH Teknik Elektro Universitas Udayana, serta data output listrik PLTS, PLTB bulan September, Oktober dan November 2017. Simulasi HOMER dilakukan dengan menggunakan potensi radiasi matahari, potensi angin, data beban listrik, serta kecepatan rata-rata angin sebagai input. 


\section{MICROGRID}

Microgrid merupakan sistem distribusi skala kecil, yang terdiri dari sumber energy terdistribusi, yang meliputi mikro turbin, fuel cells, PV dan lain sebagainya, dengan media penyimpanan energi (flywheels, kapasitor energi dan baterai) serta beban yang fleksibel. Microgrid biasanya terletak pada tegangan rendah dan harus dapat bekerja pada kondisi normal (grid connected) dan kondisi operasi darurat (islanded), sehingga dapat meningkatkan keandalan [4].



Program Studi Teknik Elektro Universitas Udayana telah menerapkan microgrid system pada gedung DH Teknik Elektro. Microgrid system ini adalah bentuk kerja sama antara Program Studi Teknik Elektro Universitas Udayana dengan Kementerian ESDM (Energi dan Sumber Daya Mineral Republik Indonesia). Sistem mikrogrid ini memiliki beberapa komponen, salah satunya yaitu pembangkit listrik hibrid antara PLTS dan PLTB.

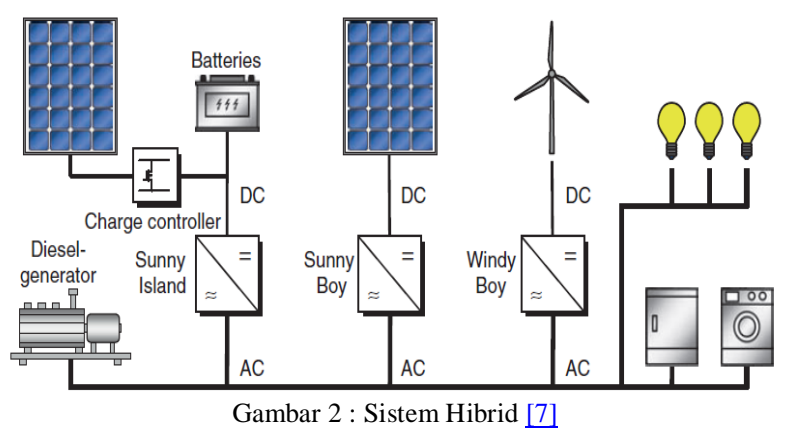

Sistem pembangkit listrik hibrid merupakan sistem yang melibatkan dua atau lebih sistem pembangkit listrik. Pada umumnya sistem pembangkit yang banyak digunakan pada sistem hybrid adalah PLTS, genset, PLTMH, dan pembangkit listrik tenaga bayu (PLTB). Kombinasi pembangkit sistem hybrid dapat dikelompokkan menjadi PLTS-genset, PLTSPLTMH, PLTS-PLTB, dan lainnya. Di Indonesia, sistem hybrid sedang berkembang, baik PLTS-genset, PLTS-PLTMH, maupun PLTS-PLTB-PLTMH [6].

\section{HASIL DAN PEMBAHASAN}

A. Sistem Kelistrikan Gedung DH Teknik Elektro Universitas Udayana

Program Studi Teknik Elektro Universitas Udayana terdiri dari 3 gedung yaitu gedung DH, gedung DI dan gedung DJ. Sistem mikrogrid terletak di gedung DH Teknik Elektro. Gedung DH digunakan untuk sarana belajar mengajar antara dosen dengan mahasiswa. Konsumsi energi listrik yang ada di setiap kelas berasal dari berbagai macam beban, seperti beban lampu, beban AC (Air Conditioner), proyektor dan beban kotak kontak lainnya. Microgrid system gedung DH memiliki sumber pembangkit listrik energi terbarukan yang terdiri dari PLTS serta PLTB.

Pembangkit listrik utama gedung DH Teknik Elektro yaitu PLTB berjumlah 10 dengan kapasitas masing-masing 500 Watt dan PLTS 80 modul dengan kapasitas masing-masing 330Wp. Dalam sistem ini PLTS dirancang untuk mencukupi beban listrik gedung DH secara langsung, sedangkan PLTB ini dirancang untuk mengisi baterai terlebih dahulu. Output AC dari PLTB akan masuk ke sebuah rectifier dan diubah menjadi DC sebelum menuju ke baterai. Sedangkan output DC dari PV (PLTS) akan masuk ke sebuah inverter untuk diubah menjadi AC sebelum memenuhi kebutuhan listrik gedung DH. Output PLTB dan PLTS, serta beban listrik gedung DH terekam langsung ke web sistem smart microgrid monitoring P3TKEBTKE Udayana. Proses perekaman secara real time ini dibantu oleh alat Power and Energy Meter bernama "Acuvim II Series".

Output PLTS yang telah berupa listrik AC akan masuk ke bidirectional inverter dan akan menuju beban. Output PLTB berupa DC akan menuju ke media penyimpanan yaitu baterai $192 \mathrm{kVAh}$ sebelum masuk ke beban. Apabila beban listrik rendah, sedangkan pembangkitan listrik tinggi maka output akan digunakan untuk charging baterai. Ketika SOC (State Of Charge) baterai mencapai kondisi penuh, maka kondisi kelebihan energi listrik (excess energy electricity) akan terjadi dan energi listrik tersebut akan terbuang. Apabila baterai berada dalam kondisi charging, maka baterai tidak dapat bersamaan menyuplai beban gedung DH. Pada siang hari, baterai akan mengalami charging apabila terdapat output PLTS yang tidak terpakai untuk beban gedung DH. Kondisi charging baterai akan menjadi discharge ketika SOC baterai mencapai $98 \%$, sedangkan apabila SOC baterai menunjukkan $\leq 40 \%$ dan tidak ada charging dari PLTS dan PLTB tidak memenuhi suplai daya listrik ke baterai maka jaringan PLN akan masuk dan charging baterai hingga menunjukkan SOC 80\%. Skema mikrogrid di Program Studi Teknik Elektro ditunjukkan pada gambar 3 . 


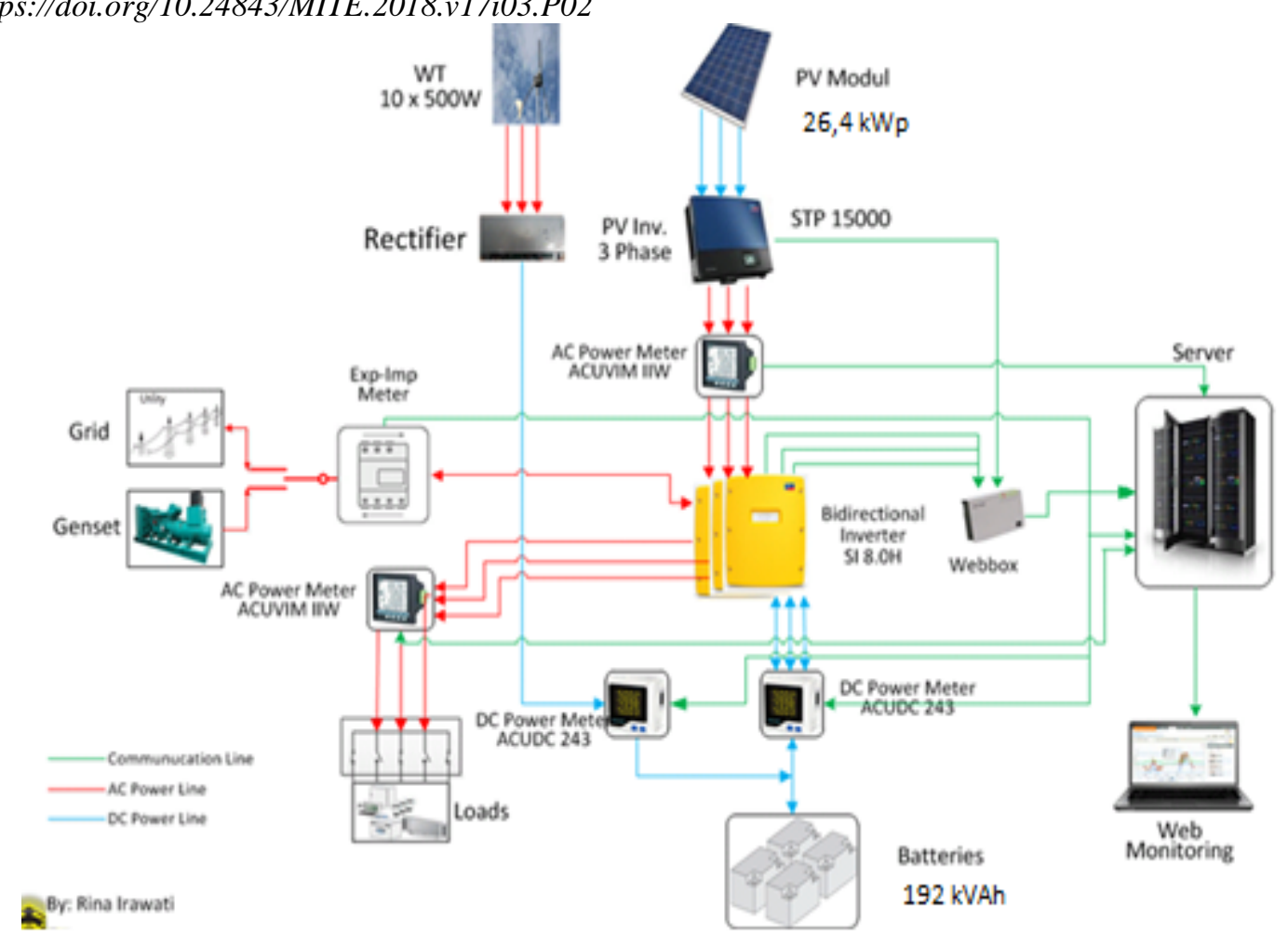

Gambar 3 : Skema Mikrogrid Gedung DH Teknik Elektro Universitas Udayana [3]

\section{B. Data Pengukuran Beban Listrik Gedung DH Teknik} Elektro Universitas Udayana

Pengukuran beban listrik yang ada di gedung $\mathrm{DH}$ diperoleh dengan bantuan Power and Energy Meter "Acuvim II series" yang terekam langsung ke web sistem smart microgrid P3TKEBTKE Udayana. Data konsumsi energi listrik yang digunakan untuk mendukung kajian dan evaluasi sistem suplai pembangkitan hibrid gedung DH yaitu data beban bulan September 2017, Oktober 2017, hingga November 2017. Data konsumsi energi listrik 3 bulan tersebut digunakan dikarenakan data sistem pembangkitan yang terekam lebih lengkap oleh web sistem smart microgrid ada pada bulan-bulan tersebut. Ketiga bulan tersebut menunjukkan kondisi beban listrik yang mengalami peningkatan mulai pukul 08.00 WITA hingga mengalami penurunan kembali pada sore hari, hal ini dikarenakan adanya aktifitas perkuliahan pada pukul 08.00 WITA dan berakhir pada 16.00 WITA. Gambar 4 juga menunjukkan beban listrik yang berbeda beda setiap bulannya pada pukul 00.00 WITA - 06.00 WITA dan 18.00 WITA - 23.00 WITA.

Rata-rata beban listrik tertinggi yaitu berada pada bulan September 2017 sebesar 6,76772 kW dan yang terendah berada pada bulan November 2017 sebesar 4,69625 kW. Sedangkan rata-rata beban untuk 3 bulan tersebut yaitu $5,55921 \mathrm{~kW}$. Kondisi beban listrik gedung DH ditunjukkan pada gambar 4.

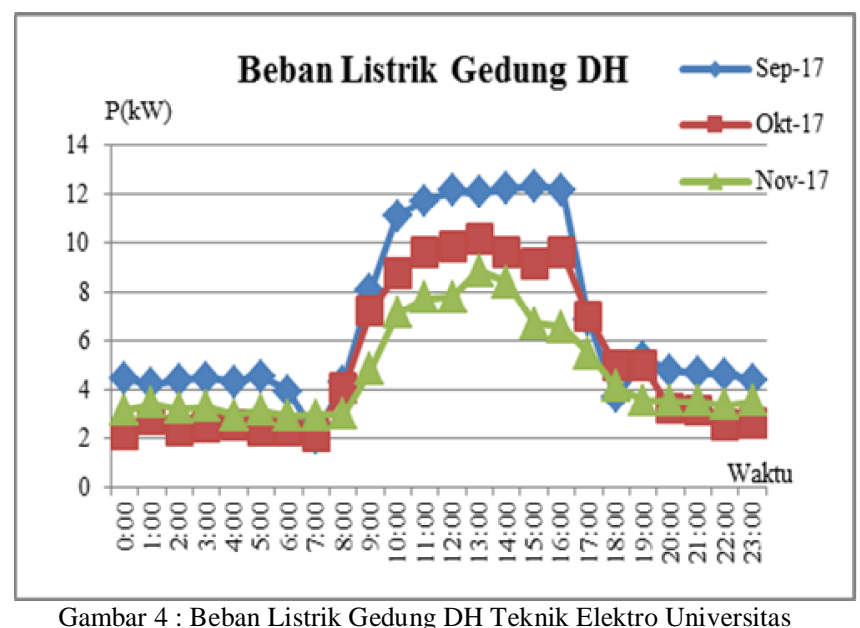

Gambar 4 : Beban Listrik Gedung DH Teknik Elektro Universitas Udayana

Konsumsi energi listrik gedung DH yang berbeda-beda dapat dipengaruhi oleh suhu pada 3 bulan tersebut. Contohnya, semakin tinggi suhu suatu wilayah maka air conditioner akan lebih bekerja keras. Pada 3 bulan yang dianalisis, bulan September mempunyai rata-rata beban listrik yang paling tinggi terkorelasi dengan suhu tertinggi, sedangkan rata-rata beban listrik dengan terkorelasi suhu terendah yaitu bulan November. Suhu rata-rata dalam tahun 2017 terekam di software HOBOware dengan sensor suhu yang terletak di lingkungan Teknik Elektro seperti yang ditunjukkan pada tabel I. 
TABEL I

DATA SUHU TEKNIK ELEKTRO TAHUN 2017

\begin{tabular}{|c|c|}
\hline Bulan & Suhu ( F) \\
\hline Januari & 151,12 \\
Februari & 142,65 \\
Maret & 113,91 \\
April & 122,48 \\
Mei & 108,50 \\
Juni & 298,99 \\
Juli & 195,64 \\
Agustus & 444,63 \\
September & 364,18 \\
Oktober & 336,00 \\
\hline November & 322,46 \\
\hline Desember & 359,88 \\
\hline Rata-rata & 246,70 \\
\hline
\end{tabular}

C. PLTS di Gedung DH Program Studi Teknik Elektro Universitas Udayana

PLTS yang berada di Teknik Elektro Universitas Udayana ditunjukkan pada gambar 5 .

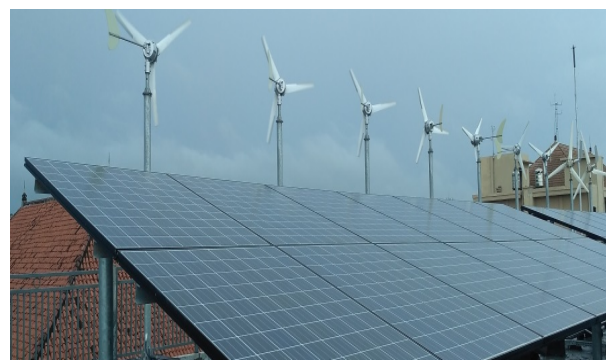

Gambar 5 : PLTS di Gedung DH Teknik Elektro Unversitas Udayana

Output dari suatu PLTS dipengaruhi oleh adanya iradiasi matahari. Dari hasil weather station rata-rata iradiasi harian matahari yang berada di wilayah Program Studi Teknik Elektro Udayana Bukit Jimbaran yaitu $4,57 \mathrm{kWh} / \mathrm{m}^{2} /$ hari seperti yang ditunjukkan pada tabel II. Data iradiasi matahari ini terekam pada software HOBOware melalui sensor radiasi matahari yang terletak di lingkungan Teknik Elektro. Tabel II menunjukkan grafik iradiasi matahari dan clearness index selama tahun 2017. Clearness index adalah kejernihan suatu atmosfer bumi, semakin tinggi clearness index, maka makin besar iradiasi matahari. Kolom clearness index diperoleh dari hasil perhitungan HOMER ketika memasukkan nilai radiasi matahari. Pada tabel II, clearness index dan radiasi matahari paling tinggi ditunjukkan pada bulan September 2017.
RATA-RATA BULANAN SOLAR GLOBAL HORIZONTAL IRRADIANCE (GHI) 2017

\begin{tabular}{|c|c|c|}
\hline Bulan & $\begin{array}{c}\text { Radiasi } \\
\text { Harian } \\
\left(\mathrm{kWh} / \mathrm{m}^{2} / \text { hari }\right)\end{array}$ & $\begin{array}{c}\text { Clearness } \\
\text { Index }\end{array}$ \\
\hline Januari & 4,11 & 0,378 \\
Februari & 4,26 & 0,392 \\
Maret & 4,98 & 0,475 \\
April & 5,10 & 0,527 \\
Mei & 4,87 & 0,556 \\
Juni & 3,48 & 0,421 \\
Juli & 4,53 & 0,535 \\
Agustus & 4,81 & 0,520 \\
September & 5,64 & 0,557 \\
Oktober & 5,18 & 0,485 \\
November & 4,07 & 0,376 \\
Desember & 3,80 & 0,351 \\
\hline Rata-rata & 4,57 & 0,460 \\
\hline
\end{tabular}

Output PLTS yang dianalisis yaitu keluaran PLTS dari kedua inverter pada bulan September 2017, Oktober 2017, serta November 2017. Output PLTS yang ditampilkan yaitu mulai pukul 06.00 WITA-18.00 WITA, hal ini dikarenakan cahaya matahari mulai terbit dan terbenam pada pukul tersebut seperti yang ditunjukkan pada gambar 6 dan 7 .
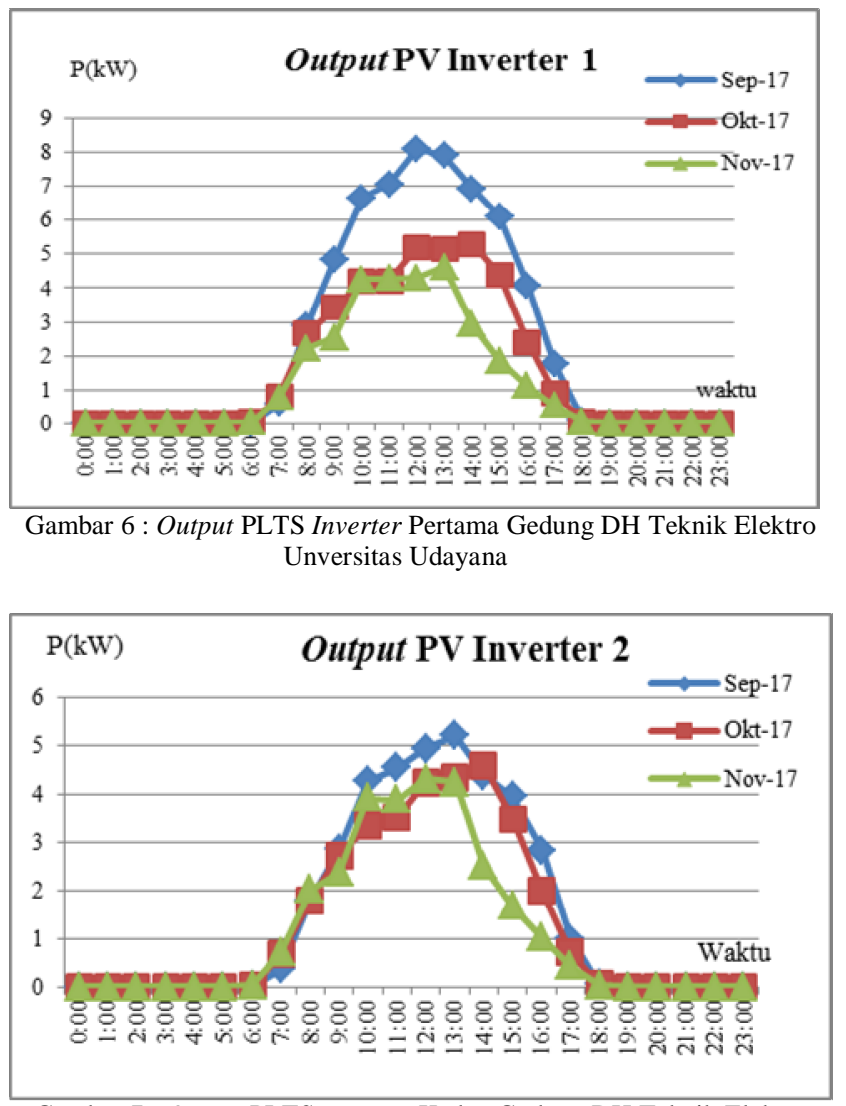

Gambar 7 : Output PLTS Inverter Kedua Gedung DH Teknik Elektro Unversitas Udayana

Total keluaran daya listrik dari PLTS inverter pertama dengan PLTS inverter kedua yaitu pada bulan September sebesar 7,760254 kW , bulan Oktober 2017 sebesar 5,847188 
kW, bulan November 2017 sebesar 4,715050 kW. Output daya listrik yang dihasilkan PLTS inverter kedua lebih kecil dari PLTS inverter pertama.

\section{PLTB di Gedung DH Program Studi Teknik Elektro} Universitas Udayana

PLTB yang berada di atap gedung DH berjumlah 10 buah wind turbine. PLTB gedung DH terdapat dua tipe yang berbeda yaitu 2 buah wind turbine berasal dari China dengan diameter bilah 1,2 meter terbuat dari fiber, sedangkan 8 wind turbine lainnya berasal dari Indonesia dengan julukan sky dancer yang dibuat oleh Ricky Elson dengan diameter bilah $80 \mathrm{~cm}$ terbuat dari kayu pinus. Setiap PLTB memiliki kapasitas pembangkitan 500 watt, sehingga total kapasitas dari seluruh PLTB dapat mencapai $5 \mathrm{~kW}$.

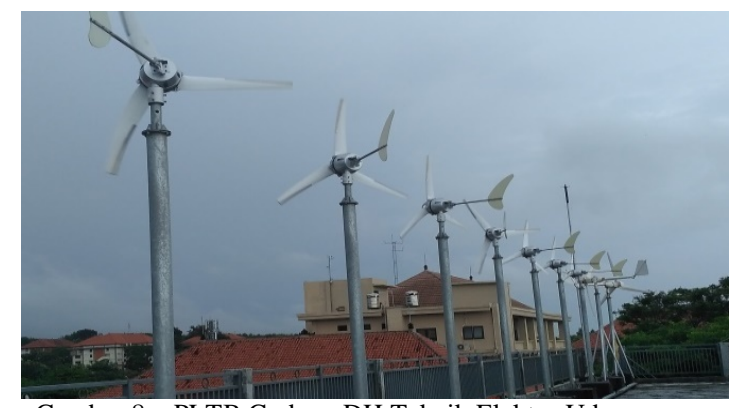

Gambar 8 : PLTB Gedung DH Teknik Elektro Udayana

Kecepatan angin sangat mempengaruhi hasil output dari sebuah PLTB, semakin besar kecepatan angin, maka semakin besar potensi PLTB untuk menghasilkan daya listrik yang besar seperti gambar 9. Data kecepatan angin yang telah direkam oleh sensor akan masuk pada software HOBOware. Data kecepatan angin selama setahun yang terdapat di lingkungan Teknik Elektro ditunjukkan pada tabel III.

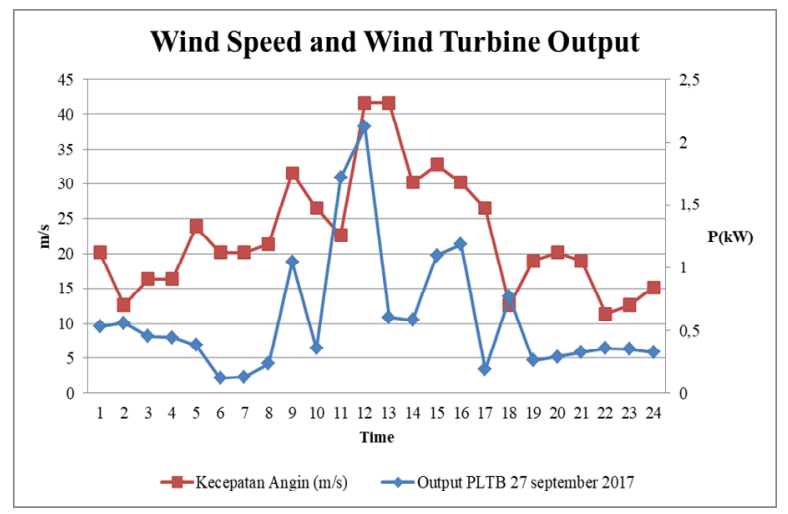

Gambar 9: Kecepatan Angin dan Output PLTB 27 September 2017 di Gedung DH Teknik Elektro Udayana

TABEL III

RATA-RATA KECEPATAN ANGIN DI TEKNIK ELEKTRO 2017

\begin{tabular}{|c|c|c|}
\hline Bulan & $\begin{array}{c}\text { Kecepatan Angin (m/s) } \\
\text { Teknik Elektro }\end{array}$ & Arah Asal Angin \\
\hline
\end{tabular}

\begin{tabular}{|c|c|c|}
\hline Januari & 10,29 & Barat \\
Februari & 13,89 & Barat \\
Maret & 8,32 & Barat \\
April & 6,44 & Timur \\
Mei & 10,40 & Timur \\
Juni & 14,92 & Timur \\
Juli & 18,28 & Timur \\
Agustus & 17,61 & Timur \\
September & 11,90 & Timur \\
Oktober & 16,87 & Timur \\
November & 4,61 & Timur \\
\hline Desember & 10,20 & Barat \\
\hline Rata-rata & 11,98 & \\
\hline
\end{tabular}

Output PLTB gedung DH yang dianalisis yaitu output pada bulan September 2017, Oktober 2017, serta 2017. Data output daya listrik ini diperoleh di sebuah web smart microgrid monitoring. Output daya listrik yang dihasilkan PLTB gedung DH ini ditunjukkan pada gambar 10.

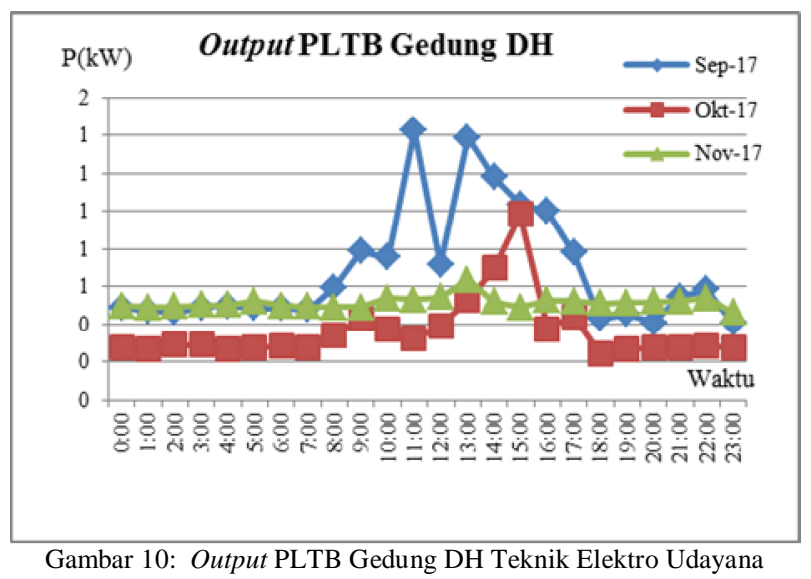

Output daya listrik dari PLTB Gedung DH ini memiliki output yang berubah-ubah, hal ini disebabkan oleh kecepatan angin yang ada di wilayah tersebut tidak menentu.

Rata-rata daya listrik tertinggi oleh PLTB ini terdapat pada bulan September 2017, yaitu sebesar 0,68086 kW. Ratarata keluaran daya listrik terendah terdapat pada bulan Oktober 2017 yaitu sebesar 0,36410 kW. Rata-rata output daya listrik dari ketiga bulan ini yaitu 0,52006 kW. Hasil ini tidak sesuai dengan potensi angin yang ada dikarenakan pada bulan Oktober banyak dilakukan perbaikan pada PLTB, sehingga banyak data yang tidak terekam pada tanggaltanggal tertentu.

\section{Analisis Output PLTS dan PLTB dengan Software HOMER \\ Free Trial Version}

Gambar 11 menunjukkan simulasi desain skematik mikrogrid di gedung DH Teknik Elektro. 




Gambar 11: Desain Skematik Mikrogrid Gedung DH Teknik Elektro Universitas Udayana

Kapasitas total pembangkitan listrik dari PLTS gedung DH dapat mencapai 26,4 kW. Akan tetapi, rata-rata daya listrik yang dapat tersuplai untuk memenuhi beban gedung DH yaitu sebesar 4,10 kW. Output maksimal yang dikeluarkan PLTB ini yaitu 23,4 kW. Adapun faktor kapasitas yang terdapat pada evaluasi tersebut diperoleh dari rata-rata output PLTS dibagi dengan kapasitas total PLTS, hasilnya yaitu sebesar 15,5\%. Produksi listrik PLTS selama setahun dapat mencapai $35956 \mathrm{kWh}$ per tahun seperti yang ditunjukkan pada tabel IV.

TABEL IV

PRODUKSI ENERGI LISTRIK PLTS SIMULASI HOMER

\begin{tabular}{|c|c|c|}
\hline Quantity & Value & Units \\
\hline Rated Capacity & 26,4 & $\mathrm{~kW}$ \\
Mean Output & 4,10 & $\mathrm{~kW}$ \\
Mean Output & 98,5 & $\mathrm{kWh} / \mathrm{d}$ \\
Capacity Factor & 15,5 & $\%$ \\
Total Production & 35956 & $\mathrm{kWh} / \mathrm{yr}$ \\
Minimum Output & 0 & $\mathrm{~kW}$ \\
Maximum Output & 23,4 & $\mathrm{~kW}$ \\
PV Penetration & 103 & $\%$ \\
Hours Of Operation & 4385 & $\mathrm{hrs} / \mathrm{yr}$ \\
\hline
\end{tabular}

Pada tabel $\mathrm{V}$ menunjukkan bahwa total kapasitas pembangkitan listrik dari PLTB gedung DH dapat mencapai $5,24 \mathrm{~kW}$. Akan tetapi, rata-rata daya listrik yang dapat tersuplai untuk memenuhi beban gedung DH yaitu sebesar $3,83 \mathrm{~kW}$. Faktor kapasitas yang terdapat pada evaluasi tersebut diperoleh dari rata-rata output PLTB dibagi dengan kapasitas total PLTB, adapun hasilnya yaitu sebesar $73 \%$. Produksi listrik PLTB selama setahun dapat mencapai 33521 $\mathrm{kWh}$ per tahun.

\begin{tabular}{|c|c|c|} 
Total Production & 33521 & $\mathrm{kWh} / \mathrm{yr}$ \\
Minimum Output & 0 & $\mathrm{~kW}$ \\
Maximum Output & 5,24 & $\mathrm{~kW}$ \\
Wind Penetration & 96,3 & $\%$ \\
Hours Of Operation & 7990 & $\mathrm{hrs} / \mathrm{yr}$ \\
\hline
\end{tabular}

Tabel VI menunjukkkan PLTS dan PLTB tidak dapat memenuhi rata-rata beban listrik pada bulan September, Oktober serta November 2017. Rata-rata beban listrik yang ada di bulan September 2017 sebesar 162,42528 kWh dan rata-rata suplai energi listrik oleh PLTS bulan September 2017 sebesar 93,12305 kWh, serta suplai energi listrik oleh PLTB bulan September 2017 sebesar 16,34064 kWh. Pada bulan Oktober 2017, rata-rata beban listrik sebesar $125,12808 \mathrm{kWh}$ dan PLTS menyuplai rata-rata energi listrik sebesar 70,16626 $\mathrm{kWh}$, serta suplai energi listrik oleh PLTB bulan Oktober 2017 sebesar 8,738400 kWh. Sedangkan rata-rata beban listrik yang ada di bulan November 2017 sebesar 112,71000 kWh dan rata-rata suplai energi listrik oleh PLTS bulan November 2017 sebesar 56,58060 kW, serta suplai energi listrik oleh PLTB bulan November 2017 sebesar 12,36576 kWh.

TABEL VI

OUTPUT PLTS DAN PLTB MELAYANI BEBAN GEDUNG DH

\begin{tabular}{|c|c|c|c|c|c|}
\hline $\begin{array}{l}\text { Bulan } \\
(2017)\end{array}$ & $\begin{array}{l}\text { Beban } \\
(k W h)\end{array}$ & $\begin{array}{c}\text { Output } \\
\text { PV } \\
\text { Inverter } \\
1 \\
\text { (kWh) }\end{array}$ & $\begin{array}{c}\text { Output } \\
\text { PV } \\
\text { Inverter } \\
2 \\
(\mathbf{k W h})\end{array}$ & $\begin{array}{c}\text { Total } \\
\text { PV } \\
\text { Inverter } \\
1 \text { dan } 2 \\
\text { (kWh) }\end{array}$ & $\begin{array}{l}\text { PLTB } \\
(\mathbf{k W h})\end{array}$ \\
\hline September & 162,42528 & 56,99916 & 36,12396 & 93,12305 & 16,34064 \\
\hline Oktober & 125,12808 & 38,70516 & 31,46112 & 70,16626 & 8,738400 \\
\hline November & 112,71000 & 29,47944 & 27,10116 & 56,58060 & 12,36576 \\
\hline
\end{tabular}

Tabel VII menunjukkan hasil produksi energi listrik PLTS dan PLTB gedung DH dalam kondisi real dan hasil simulasi.

TABEL VII

PERBANDINGAN OUTPUT PLTS DAN PLTB KONDISI REAL DAN HOMER

\begin{tabular}{|c|c|c|c|c|}
\hline & $\begin{array}{c}\text { Kondisi } \\
\text { Real Total } \\
\text { PV }\end{array}$ & $\begin{array}{c}\text { Kondisi } \\
\text { Real PLTB } \\
\text { Gedung } \\
\text { DH }\end{array}$ & $\begin{array}{c}\text { Output PV } \\
\text { Simulasi } \\
\text { HOMER }\end{array}$ & $\begin{array}{c}\text { Output } \\
\text { PLTB } \\
\text { Simulasi } \\
\text { HOMER }\end{array}$ \\
\hline $\begin{array}{c}\text { Total } \\
\text { Selama 1 } \\
\text { tahun }\end{array}$ & $\begin{array}{c}\mathrm{kWh} / \mathrm{tahun} \\
55 \%\end{array}$ & $\begin{array}{c}\mathrm{kWh} / \mathrm{tahun} \\
9 \%\end{array}$ & $\begin{array}{c}\mathrm{kWh} / \mathrm{tahun} \\
75 \%\end{array}$ & $\begin{array}{c}\mathrm{kWh} / \mathrm{tahun} \\
70 \%\end{array}$ \\
\hline
\end{tabular}

\section{KESIMPULAN}

PLTS dan PLTB di Teknik Elektro tidak dapat memenuhi beban listrik untuk gedung DH pada bulan September, Oktober serta November 2017. Total produksi energi listrik PLTS dan PLTB bulan September, Oktober dan November 2017 lebih rendah dari kondisi beban listrik selama 3 bulan 
tersebut. Ketika dilakukan sebuah simulasi selama setahun, kondisi simulasi produksi energi listrik PLTS dan PLTB selama setahun lebih besar daripada kondisi riil produksi energi listrik PLTS dan PLTB di lapangan selama setahun. Pengurangan energi listrik yang diminta dari PLN setelah adanya sistem pembangkitan listrik hibrid ini mencapai $64 \%$ dari kebutuhan total beban listrik.

\section{REFERENSI}

[1] PT. PLN (Persero). Rencana Usaha Penyediaan Tenaga Listrik (RUPTL) PT PLN (Persero) 2018-2027. Indonesia, 2018.

[2] Nurrohim, Agus. "Pembangkit Listrik Tenaga Hibrid Sebagai Solusi Kelistrikan di Daerah Terpencil". Jurnal Sains dan Teknologi Indonesia. Vol 14,No.2. 2012.

[3] IAD Giriantari, Rina Irawati. Smart Microgrid System with Supply from Hybrid. ICSGTEIS 2016. Bali, Indonesia : Udayana University, 2016.

[4] Trisnasari,C.T. "Pemodelan dan Simulasi Sistem Proteksi Microgrid". Jurnal Teknik ITS. 5(2) : 48-52. 2016.

[5] Microgrid Institute. http://www.microgridinstitute.org/. [Online]

[6] Heri Desrizal, Iswadi H R. “Analisis Ketersediaan Sistem Pembangkit Berbasiskan Pembangkit Listrik Tenaga Angin (PLTB) dan Pembangkit Listrik Tenaga Surya”. Jom FTEKNIK. Vol 5 No. 1. 2018

[7] Critical Power. https://www.criticalpowersupplies.co.uk/. [Online]

[8] Kunaifi. "Program HOMER Untuk Studi Kelayakan Pembangkit Listrik Hibrida Di Propinsi Riau". Seminar Nasional Informatika (SemnasIF) 2010. Yogyakarta : UPN Veteran Yogyakarta, 2010.

[9] Yuniari Margareta, IAD Giriantari, Sukerayasa I Wyn. 2017. Analisis Model Supply Pada Jaringan Sistem Kelistrikan di Fakultas Teknik Universitas Udayana Bukit Jimbaran. Teknologi Elektro, Vol.16, No.03 (September-Desember).

[10]Darma Putra, Krisna. 2015, Perencanaan Sistem Jaringan Mikro (Microgrid) dengan Supply dari Pembangkit Listrik Tenaga Surya (PLTS) dan Generator Set di Jurusan Teknik Elektro Universitas Udayana. Teknologi Elektro, Vol.14. No. 2 (Juli - Desember): 69-74 
\{ Halaman ini sengaja dikosongkan\} 